\title{
Pengaruh Latihan Beban Menggunakan Bench Press Terhadap Daya Ledak Otot Lengan Atlet Karate
}

\author{
Fella Maifitri \\ Universitas Negeri Padang, Indonesia \\ Jl. Prof. Dr. Hamka Kampus Air Tawar Padang \\ email: fella.maifitri@fik.unp.ac.id
}

\begin{abstract}
ABSTRAK
The problem in this study was the low ability of the muscle explosive power of the UK Karate UNP athletes. This study aims to see the effect of weight training using Bench Press on the explosive power of arm muscles of UK karate athletes at UNP. The population in this study were athletes from the Padang State University Karate Activity Unit, amounting to 15 people. Sampling is done by Total Sampling, then the sample in this study amounted to 15 people. The treatment in this study was carried out as many as 16 meetings and measurements of arm muscle explosive power before and after treatment (pretest-posttes design). The instrument used in this study was the Two Hand Medicine Ball Put test. After the data is obtained, the data is analyzed using t-test. The results showed: weight training using the Bench Press had a significant effect on the explosive power of the athlete's arm Unit of Karate University Padang State University's karate activity was proven where $t$ count $6.42>t$ table 2.15 thus the hypothesis in this study was accepted.
\end{abstract}

Kata kunci : Latihan bench press, daya ledak otot lengan

\section{PENDAHULUAN}

Karate merupakan salah satu olahraga yang besar manfaatnya. Apabila seseorang melakukan karate, maka seluruh tubuhnya selalu bergerak aktif baik tangan maupun kakinya, sehingga kesegaran jasmani pelakunya dapat meningkat. Akibat dari perkembangan ilmu pengetahuan dan teknologi (IPTEK), pada masa sekarang ini karate bukan saja merupakan olahraga semata, tetapi juga merupakan salah satu cabang olahraga yang banyak disukai oleh masyarakat untuk berbagai tujuan contohnya beladiri, kesegaran jasmani dan untuk prestasi.

Selain itu, juga banyak didirikan perkumpulan karate seperti organisasi, klub dan kelompok karate yang dibina serta diorganisir oleh Pengurus Propinsi Federasi Olahraga Karatedo Indonesia (PENGPROV FORKI). PENGPROV FORKI inilah yang membuat program pertandingan setiap tahunnya. Universitas Negeri Padang merupakan satu-satunya pusat pendidikan di Sumatera Barat yang memiliki pusat tenaga kependidikan olahraga dan pengembangan bakat olahraga, tepatnya pada Fakultas Ilmu Keolahragaan (FIK) yang bertanggung jawab terhadap pembangunan dalam bidang olahraga.

Kemudian pembinaan karate dilakukan pembinaannya melalui unit kegiatan olahraga (UKO) mahasiswa yang merupakan pusat kegiatan olahraga dari mahasiswa UNP. Pembinaan prestasi terhadap karate diarahkan kepada tim UK karate yang terdiri dari mahasiswa UNP yang masih aktif dalam perkuliahan terdaftar tahun 2007-2012. Rata-rata mereka telah memiliki kemampuan standar sebagai atlet karate, karena merupakan mantan atlet Pekan Olahraga Daerah (PORDA). 


\section{MAJALAH ILMIAH}

http : //1ppm.upiyptk.ac . id/ojs 3/index.php/MAJALAHILMIAH/index

Dalam peningkatan prestasi karate yang merupakan cabang olahraga yang sangat rumit dan kompleks, ada 4 komponen yang harus mendapatkan perhatian yaitu ; kondisi fisik, teknik, taktik dan mental. Hal ini sesuai dengan yang dikemukakan Syafruddin (2011:54) yaitu, "Prestasi olahraga dipengaruhi dan ditentukan oleh kemampuan atlet itu sendiri secara menyeluruh baik menyangkut kemampuan fisiknya, teknik, taktik maupun oleh kemampuan mental (psikis) nya". Oleh karena itu untuk memenuhi hal tersebut atlet harus memiliki empat komponen prestasi yang baik, terutama kondisi fisik. Kondisi fisik merupakan salah satu komponen yang dimaksud di atas harus mendapatkan perhatian yang serius dari pembina sebab kondisi fisik merupakan pondasi dasar dalam peningkatan kemampuan lainnya dimiliki oleh setiap atlet apabila meraih prestasi yang tinggi. (Syafruddin, 2011:54).

Sesuai dengan pendapat Arsil (2008:7) mengatakan bahwa tujuan pembinaan kondisi fisik adalah, "Untuk menyempurnakan teknik dari olahraga yang dipilih atau dibina". Komponen kondisi fisik itu sendiri dapat ditinjau dari konsep muskular meliputi daya tahan (Endurance), kekuatan (Strength), daya ledak (Power), kecepatan (Vilocity/ Speed), kelentukan (Flexibility), kelincahan (Agility), kesimbangan (Balance), dan koordinasi (Coordination). Berdasarkan pendapat di atas dapat dikemukakan bahwa penguasaan teknik dapat direalisasikan secara efektif jika didukung oleh tingkat kondisi fisik yang baik.

Seperti beladiri lainnya karate juga mempunyai suatu teknik pukulan, yaitu pukulan yang dilancarkan kedepan dengan ditumbukkan kepada sasaran (Hamid, 2007:33). Oleh sebab itu, seorang atlet karate harus menguasai teknik pukulan secara baik karena teknik pukulan merupakan teknik dasar dalam menyusun serangan sebelum terjadinya kesempatan untuk mendapatkan poin.

Kemampuan atlet untuk melakukan teknik pukulan haruslah konsisten antara pukulan yang dilancarkan kedepan dengan ditumbukkan kepada sasaran. Untuk melatih hal tersebut, kondisi fisik daya ledak otot lengan sangat berperan penting dalam latihan teknik pukulan ini karena selain teknik pukulan yang kuat, juga diperlukan kecepatan dalam melakukan teknik tersebut. Kondisi fisik daya ledak otot lengan ini dituangkan dalam suatu bentuk latihan agar teknik pukulan menjadi bagus dan maksimal.

Berdasarkan pendapat di atas jelaslah bahwa daya ledak otot lengan merupakan faktor dominan yang mempengaruhi teknik pukulan, serta bentuk latihan adalah sarana penyempurnaan daya ledak otot lengan tersebut. Daya ledak otot lengan merupakan kemampuan otot lengan mengarahkan kekuatan dengan cepat dalam waktu yang singkat. Berdasarkan pemantauan peneliti yang juga pernah menjadi atlet UK karate UNP, dan dibenarkan oleh Septri, S.Si selaku asisten dosen FIK UNP dan sebagai pelatih UK karate UNP menyatakan bahwa, "Daya ledak otot lengan atlet UK karate UNP kurang bagus dan tidak maksimal". Hal ini dapat dilihat dari setiap latihan yang diikuti atlet UK karate UNP, daya ledak otot lengan teknik pukulan yang dilakukan kurang mempunyai kekuatan dan kurang cepat. Sedangkan dalam karate, daya ledak otot lengan sangat diperlukan dalam teknik pukulan.

Memang perkembangan prestasi atlet UK karate UNP sudah bagus, tetapi dari segi kondisi fisik daya ledak otot lengan atlet masih kurang bagus sehingga teknik pukulan kurang maksimal . Ini diduga karena bentuk latihan atlet yang monoton atau latihan yang hanya dilakukan dalam satu bentuk latihan saja, sehingga atlet UK karate UNP menjadi bosan / jenuh. Oleh sebab itu apabila terus dibiarkan, maka prestasi yang ditorehkan oleh atlet UK karate UNP akan semakin menurun dan susah untuk bersaing ditingkat yang lebih tinggi.

\section{TINJAUAN PUSTAKA}




\section{MAJALAH ILMIAH}

http : //1ppm.upiyptk.ac . id/ojs 3/index.php/MAJALAHILMIAH/index

\section{Karate}

Karate atau karate-do adalah salah satu seni beladiri dari Jepang yang merupakan salah satu cabang olahraga beladiri dengan menggunakan tangan kosong dan kaki untuk melumpuhkan lawan, atau beladiri yang hanya menggunakan anggota badan seperti tangan dan kaki sebagai pengganti senjata (Sujoto dalam Martinel, 2008:7). Pada umumnya karate lebih digambarkan dengan gerakan serangan, serta belaan tangan dan kaki secara menyeluruh. Teknik dasar karate menurut Hamid (2007:4) terbagi menjadi tiga aspek pokok, yaitu Kihon (teknik dasar), Kata (jurus) dan Kumite (pertarungan).

Kihon secara harfiah berarti dasar atau fondasi. Karateka (orang yang mempraktekkan karate) harus menguasai kihon dengan baik sebelum mempelajari kata dan kumite. Kata secara harfiah berarti bentuk atau pola. Kata dalam karate tidak hanya merupakan latihan fisik atau latihan aerobik biasa. Tapi juga mengandung pelajaran tentang prinsip bertarung. Setiap kata memiliki ritme gerakan dan pernapasan yang berbeda. Kumite secara harfiah berarti pertemuan tangan. Kumite dilakukan oleh murid-murid tingkat lanjut (sabuk biru atau lebih). Tetapi sekarang, ada dojo (tempat berlatih karate) yang mengajarkan kumite pada murid tingkat pemula (sabuk kuning).

Pertandingan karate dibagi atas dua jenis yaitu Kumite (perkelahian) putera dan puteri dan Kata (jurus) putera dan puteri. Kumite dibagi atas kumite perorangan dengan pembagian kelas berdasarkan berat badan, dan kumite beregu tanpa pembagian kelas berat badan (khusus untuk putera). Sistem pertandingan yang dipakai adalah Reperchance (WUKO) atau babak kesempatan kembali kepada atlet yang pernah dikalahkan oleh sang juara. Pertandingan dilakukan dalam satu babak 2-3 menit bersih dan satu babak perpanjangan kalau terjadi seri, kecuali dalam pertandingan beregu tidak ada waktu perpanjangan. Dan jika masih pada babak perpanjangan masih mengalami nilai seri, maka akan diadakan pemilihan karateka yang paling ofensif dan agresif sebagai pemenang.

Pada pertandingan kata yang diperagakan adalah keindahan gerak dari jurus, baik untuk putera maupun puteri. Sesuai dengan kata pilihan atau kata wajib dalam peraturan pertandingan. Para peserta harus memperagakan kata wajib. Bila lulus, peserta akan mengikuti babak selanjutnya dan dapat memperagakan kata pilihan. Pertandingan dibagi menjadi dua jenis, yaitu kata perorangan dan kata beregu. Kata beregu dilakukan oleh tiga orang.

\section{Daya Ledak Otot Lengan}

Kondisi fisik yang dimiliki oleh atlet atau olahragawan yang berprestasi, hendaknya memperhatikan unsur-unsur kondisi fisik seperti kekuatan, daya tahan, kecepatan, kelincahan, koordinasi dan beberapa unsur lainnya. Unsur kondisi fisik yang didukung oleh dua komponen kondisi fisik antara kekuatan dan kecepatan, sering dikatakan dengan daya ledak (Eksplosive Power).

Daya ledak merupakan salah satu komponen biomotorik yang sangat penting dalam kegiatan olahraga, karena daya ledak akan menentukan seberapa kerasnya orang dapat memukul, seberapa tinggi dapat melompat, seberapa cepat dapat berlari dan sebagainya. Bompa dalam Syafruddin (2011 : 72-73) mendefinisikan, "Daya ledak sebagai produk dari dua kemampuan yaitu kekuatan (Strength) dan kecepatan (Speed) untuk melakukan force maksimum dalam waktu yang cepat".

Sejalan dengan pendapat Jonath dan Krempel dalam Syafruddin (2011:73) yang menjelaskan bahwa, "Daya ledak sebagai kemampuan kombinasi kekuatan dan kecepatan yang terealisasi dalam bentuk kemampuan otot untuk mengatasi beban dengan kecepatan kontraksi yang tinggi". Letzelter dalam Syafruddin (2011:73) mengemukakan bahwa, "Kemampuan daya ledak berada 
http://1ppm.upiyptk.ac. id/ojs3/index.php/MAJALAHILMIAH/index

antara kekuatan maksimal dan kecepatan gerakan yang cenderung bergerak lebih kearah kecepatan gerakan / kearah kekuatan maksimal menurut besarnya beban/hambatan".

Berdasarkan beberapa pendapat dan penjelasan diatas, maka dapat disimpulkan bahwa daya ledak adalah kemampuan mengarahkan kekuatan dengan cepat dalam waktu yang sangat singkat untuk memberikan momentum yang paling baik pada tubuh dalam suatu gerakan yang cepat untuk mencapai tujuan yang dikehendaki.

Daya ledak menurut macamnya ada dua, yaitu daya ledak absolut dan daya ledak relatif. Daya ledak absolut adalah kekuatan untuk mengatasi suatu beban eksternal yang maksimum, sedangkan daya ledak relatif adalah kekuatan untuk mengatasi beban berupa berat badan sendiri (Arsil, 2008:74). Menurut Nossek dalam Arsil (2008:74) faktor yang mempengaruhi daya ledak adalah :

1. Kekuatan

Kekuatan merupakan salah satu komponen yang sangat penting untuk menunjang aktivitas fisik, khususnya dalam berolahraga. Komponen ini mutlak diperlukan untuk meraih prestasi puncak. Hal ini Syafruddin dalam Fachreza (2010:20) bahwa, "Setiap penampilan dalam olahraga memerlukan kekuatan otot disamping unsur-unsur lainnya yang diperlukan".

2. Kecepatan Kontraksi

Kecepatan kontraksi otot yang terkait (serabut otot lambat dan serabut otot cepat), besarnya beban yang digerakkan, kontraksi otot intra dan otot ekstra, panjang otot pada waktu kontraksi dan sudut sendi. Metode latihan daya ledak menurut Suharno dalam Arsil (2008:75) dapat dilakukan dengan antara lain :

- Latihan sirkuit.

- Latihan beban.

- Latihan interval.

Beberapa metode latihan daya ledak yang disusun para ahli, antara lain :

a. Menurut Soeharsono dalam Arsil (2008:76)

Beban latihan (intensitas) : $40 \%-60 \%$ (beban maksimal).

Set latihan : 4 - 6 set.

Ulangan perset (repetisi) $\quad:$ Tidak boleh melebihi kemampuan repetisi maksimal.

Irama gerakan : Gerakan yang selaras dan dinamis.

b. Menurut Nossek dalam Arsil (2008:76)

Beban latihan (intensitas) : 50\%-75\% (beban maksimal).

Set latihan : $\quad: 4-6$ set.

Ulangan perset (repetisi) $\quad: 6-10$ kali.

Interval : $3-5$ set.

Irama gerakan : Eksplosif / cepat.

c. Menurut Harre dalam Arsil (2008:76)

Beban latihan (intensitas) : 30\%-50\% (beban maksimal).

Set latihan (intensitas) : $\quad 3-5$ set.

Ulangan perset (repetisi) : $8-12$ kali.

Interval : 2 - 5 menit

Irama gerakan : Eksplosif / cepat.

Metode pengembangan daya ledak ada 3, yaitu :

1. Meningkatkan kekuatan dan kecepatan secara bersama - sama. 


\section{MAJALAH ILMIAH}

http://1ppm.upiyptk.ac.id/ojs3/index.php/MAJALAHILMIAH/index

Soebroto dalam Arsil (2008:77) mengemukakan, "Latihan kekuatan dan kecepatan secara bersamaan diberikan dengan pembebanan sedang, ini memberikan pengaruh yang lebih baik terhadap nilai dinamis jika dibandingkan dengan latihan kekuatan saja”.

2. Meningkatkan kekuatan tanpa mengabaikan kecepatan.

Menurut O'Shea dalam Arsil (2008:77) bahwa, "Latihan daya ledak yang menitikberatkan pada kekuatan, intensitas latihan pembebanannya adalah submaksimal dengan kecepatan kontraksi antara 7 - 10 detik dan pengulangan 8 - 10”.

3. Meningkatkan kecepatan tanpa mengabaikan kekuatan.

Bompa dalam Arsil (2008:78) bahwa, "Latihan daya ledak dengan penekanan kecepatan rangsang mendapat pembebanan sedang atau pembebanan ringan".

Otot lengan terdiri dari biceps, triceps dan forearm (Aderai, 2006:59). Otot merupakan bangun - bangun tersendiri dan bila mengerut menyebabkan gerak pada sendi tersebut oleh Fitrawati dalam Fachreza (2010:20). Dalam hal ini Syafrudin dalam Fachreza (2010:20) menyatakan bahwa, "Setiap penampilan dalam olahraga memerlukan kekuatan otot disamping unsur-unsur lainnya yang diperlukan". Susunan otot lengan terdiri dari dua bagian, yaitu lengan bagian atas dan lengan bagian bawah. Bagian atas berpangkal dari sendi bahu dan berujung pada sendi siku, sedangkan bagian bawah berpangkal dari sendi siku dan berujung pada sendi pergelangan tangan.

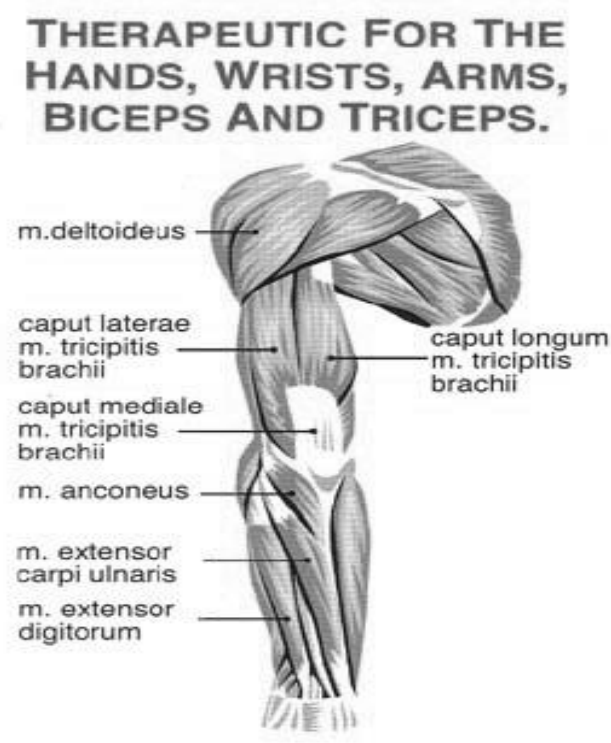

Gambar 1. Otot Lengan

(Sumber : $\underline{\text { http://www.shocktreatment.com.au/arm\%20muscle.gif) }}$

Dari uraian diatas dapat disimpulkan bahwa, daya ledak otot lengan adalah kemampuan seseorang mengarahkan kekuatan dengan cepat dalam waktu yang sangat singkat, serta untuk memberikan momentum yang paling baik pada otot lengan dalam suatu gerakan yang cepat dalam melakukan aktivitas olahraga.

\section{Latihan Beban Bench Press}




\section{MAJALAH ILMIAH}

http : //1ppm.upiyptk.ac . id/ojs 3/index.php/MAJALAHILMIAH/index

Latihan adalah suatu proses pengolahan/penerapan materi latihan seperti keterampilanketerampilan gerakan dalam bentuk pelaksanaan yang berulang-ulang dan melalui tuntutan yang bervariasi (Röthig at al dalam Syafruddin, 2011:21). Menurut Hardiansyah (2017) latihan adalah suatu aktifitas yang dilakukan dengan tujuan tertentu yang dilakukan secara berulang-ulang, hal senada diungkapkan oleh Bompa dalam Febrina (2009:21), "Latihan merupakan proses pengulangan yang sistematis, progresif dengan tujuan akhir memperbaiki prestasi olahraga". Tujuan dari latihan adalah memperoleh hasil peningkatan keterampilan kebugaran jasmani/fisik tubuh yang maksimal yang lebih baik dari hari ke hari sesuai hasil yang diinginkan. Menurut Syafruddin (2011:30) beban adalah sesuatu, baik berupa benda atau tidak, yang dapat membebani dan mempengaruhi keadaan fisik dan psikis (mental).

Latihan beban (Weight Resistence Training) adalah suatu kegiatan yang dilakukan secara berulang - ulang dengan segala tuntutan didalam latihan baik berupa tuntutan fisik atau psikis (mental). Latihan beban bertujuan untuk meningkatkan kekuatan otot rangka (Bowers dalam Arsil, 2008 : 50-51). Swensen dalam Arsil (2008:51) mengatakan, dengan melakukan latihan beban secara benar dapat meningkatkan kekuatan otot serta mampu meningkatkan koordinasi motor unit yang berbeda dalam otot yang sama maupun didalam berbagai otot yang ikut terlibat pada suatu aktivitas fisik. Latihan beban dilakukan untuk meningkatkan kinerja para pekerja berat dan atlet laki - laki dan wanita (Kirkley dan Godbody dalam Arsil, (2008:51).

Bench Press adalah alat pangangkat daya atau tenaga yang digunakan secara ekstensif pada latihan berat yang bertujuan untuk pembentukan tubuh, dan merupakan tipe latihan fitness untuk perkembangan dada dan lengan. Latihan beban menggunakan Bench Press adalah latihan beban yang melatih tubuh bagian atas yang bertujuan untuk merangsang dada dan lengan (deltoid dan trisep). Latihan ini berfokus kepada perkembangan otot besar dada yang mencangkup deltoid depan, serratus depan, scapulae fixers, trapezii, dan trisep.

Dari penjelasan diatas diketahui bahwa, daya ledak otot lengan sangat berperan penting dalam karate, apabila daya ledak otot lengan kurang baik, maka teknik pukulan kurang mempunyai kekuatan dan kurang cepat. Sangat penting artinya bagi seorang atlet atau orang orang yang terkait didalamnya mengetahui hal ini agar lebih mementingkan latihan untuk melatih daya ledak otot lengan mereka.

\section{METODOLOGI PENELITIAN}

Jenis penelitian ini adalah Quaci Experiment atau eksperimen semu, yaitu penelitian eksperimen yang menggunakan manusia sebagai subyek penelitiannya. Tujuan penelitian ini adalah untuk mencari seberapa besar pengaruh latihan beban menggunakan Bench Press terhadap daya ledak otot lengan atlet UK karate UNP. Populasi dalam penelitian ini adalah seluruh atlet putra UK karate UNP yang masih aktif dalam perkuliahan yang terdaftar tahun 2007-2012 dan telah memiliki kemampuan standar sebagai atlet beladiri karate. Berdasarkan pengamatan dan data pelatih, seluruh atlet putra UK karate UNP tersebut berjumlah sebanyak 15 orang. Seluruh populasi dijadikan sebagai sampel. Instrument yang digunakan dalam penelitian ini adalah tes Two Hand Medicine. Menurut Barry L. Jhonson dalam Fachreza, (2010: 30-31) untuk mengukur daya ledak tes yang digunakan adalah Two Hand Medicine Ball Putt Test dengan tingkat reliabilitas 0.84 , validitas 0.77 dan berat $6 \mathrm{lb}(1 \mathrm{~kg}=2.2046 \mathrm{lb})=2.72 \mathrm{~kg}$.

\section{HASIL PENELITIAN \\ Deskripsi Data}

a. Pre Test 


\section{MAJALAH ILMIAH}

http://1ppm.upiyptk.ac . id/ojs3/index.php/MAJALAHILMIAH/index

Berdasarkan analisis terhadap data tes awal maka Pengaruh Latihan Beban Menggunakan Bench Press Terhadap Daya Ledak Otot Lengan Atlet UK Karate UNP menunjukkan hasil sebagai berikut: skor tertinggi 3.40 dan skor terendah adalah 2.34 dengan rata-rata 2.78 dan standar deviasi 0.27 . Untuk lebih jelasnya akan dibuatkan tabel distribusi frekuensi di bawah ini:

Tabel 1: Data Hasil Tes Awal Pengaruh Latihan Beban Menggunakan Bench Press Terhadap Daya Ledak Otot Lengan Atlet UK Karate UNP (Pree Test)

\begin{tabular}{|c|c|c|c|}
\hline No & Kelas Interval & $\begin{array}{c}\text { Frekuensi } \\
\text { Absolut (Fa) }\end{array}$ & $\begin{array}{c}\text { Frekuensi } \\
\text { Relatif (Fr \%) }\end{array}$ \\
\hline 1 & $2.34-2.55$ & 3 & 20 \\
\hline 2 & $2.56-2.77$ & 5 & 33.33 \\
\hline 3 & $2.78-2.99$ & 4 & 26.67 \\
\hline 4 & $3.00-3.21$ & 2 & 13.33 \\
\hline 5 & $3.22-3.43$ & 1 & 6.67 \\
\hline \multicolumn{2}{|r|}{ Jumlah } & 15 & $100 \%$ \\
\hline
\end{tabular}

Berdasarkan data distribusi frekuensi diatas, persentasi dari 15 orang sampel ternyata sebanyak 3 orang sampel (20\%) memiliki hasil daya ledak otot lengan dengan kelas interval 2.34-2.55, kemudian sebanyak 5 orang sampel (33.33\%) memiliki hasil daya ledak otot lengan dengan kelas interval 2.56-2.77, selanjutnya ada sebanyak 4 orang sampel (26.67\%) memiliki hasil daya ledak otot lengan dengan kelas interval 2.78-2.99, sedangkan sebanyak 2 orang sampel (13.33\%) memiliki hasil daya ledak otot lengan dengan kelas interval 3.00-3.21, dan sisanya ada 1 orang sampel lagi (6.67\%) memiliki hasil daya ledak otot lengan dengan kelas interval 3.22-3.43. Untuk lebih jelasnya dapat dilihat pada grafik berikut:

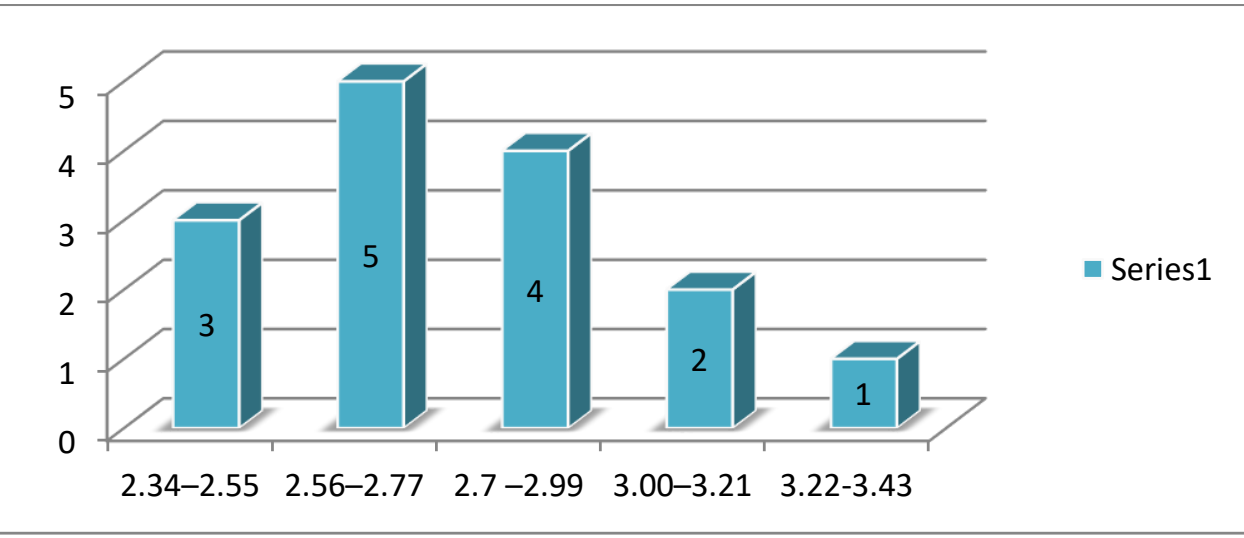

Grafik 1. Hasil Tes Awal Pengaruh Latihan Beban Menggunakan Bench Press Terhadap Daya Ledak Otot Lengan Atlet UK Karate UNP Sumber: data penelitian peneliti

\section{b. Post Test}




\section{MAJALAH ILMIAH}

http://1ppm.upiyptk.ac . id/ojs3/index.php/MAJALAHILMIAH/index

Pengaruh Latihan Beban Menggunakan Bench Press Terhadap Daya Ledak Otot Lengan Atlet UK Karate UNP (Pos Test). Berdasarkan analisis terhadap data tes akhir maka Pengaruh Latihan Beban Menggunakan Bench Press Terhadap Daya Ledak Otot Lengan Atlet UK Karate UNP (Pos Test) menunjukkan hasil sebagai berikut: skor tertinggi 3.47 dan skor terendah adalah 2.47 dengan rata-rata 2.95 dan standar deviasi 0.3311 . Untuk lebih jelasnya akan dibuatkan tabel distribusi frekuensi di bawah ini:

Tabel 2. Data Hasil Tes Akhir Pengaruh Latihan Beban Menggunakan Bench Press Terhadap Daya Ledak Otot Lengan Atlet UK Karate UNP (Pos Test)

\begin{tabular}{|c|c|c|c|}
\hline No & Kelas Interval & $\begin{array}{c}\text { Frekuensi } \\
\text { Absolut (Fa) }\end{array}$ & $\begin{array}{c}\text { Frekuensi } \\
\text { Relatif (Fr\%) }\end{array}$ \\
\hline 1 & $2.47-2.67$ & 4 & 26.67 \\
\hline 2 & $2.68-2.88$ & 3 & 20 \\
\hline 3 & $2.89-3.09$ & 1 & 6.67 \\
\hline 4 & $3.10-3.30$ & 4 & 26.67 \\
\hline 5 & $3.31-3.51$ & 3 & 20 \\
\hline \multicolumn{2}{|r|}{ Jumlah } & 15 & $100 \%$ \\
\hline
\end{tabular}

Berdasarkan data distribusi ferkuensi diatas, persentasi dari 15 orang sampel ternyata sebanyak 4 orang sampel $(26.67 \%)$ memiliki hasil daya ledak otot lengan dengan kelas interval 2.47-2.67, kemudian sebanyak 3 orang sampel (20\%) memiliki hasil daya ledak otot lengan dengan kelas interval 2.68-2.88, selanjutnya ada sebanyak 1 orang sampel $(6.67 \%)$ memiliki hasil daya ledak otot lengan dengan kelas interval 2.89-3.09, sedangkan 4 orang sampel (26.67\%) memiliki hasil daya ledak otot lengan dengan kelas interval 3.10-3.30 dan sebanyak 3 orang sampel (20\%) memiliki hasil daya ledak otot lengan dengan kelas interval 3.31-3.51, Untuk lebih jelasnya dapat dilihat pada grafik berikut:

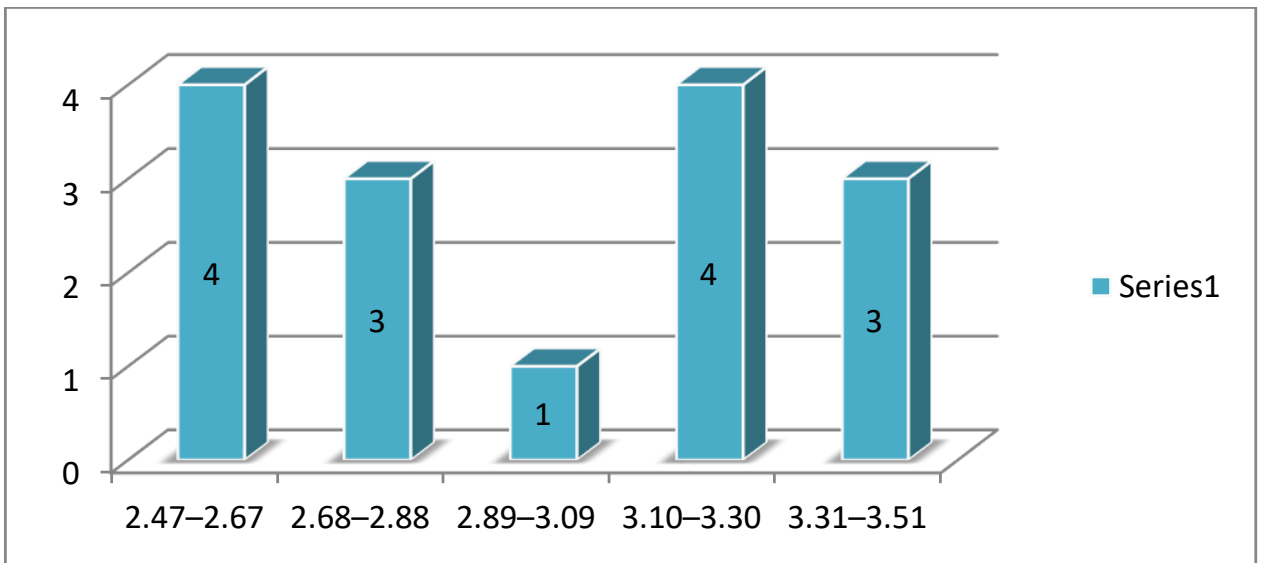

Grafik 2. Hasil Tes Akhir Pengaruh Latihan Beban Menggunakan Bench Press Terhadap Daya Ledak Otot Lengan Atlet UK Karate UNP Sumber: data penelitian peneliti

\section{c. Uji persyaratan analisis dengan uji Lilliefors}


http://1ppm.upiyptk.ac. id/ojs3/index.php/MAJALAHILMIAH/index

Analisis uji normalitas data dilakukan dengan uji Lilliefors. Hasil analisis uji normalitas masing-masing variabel di sajikan dalam bentuk tabel di bawah ini, dan perhitungan lengkapnya dapat dilihat pada lampiran.

Tabel 3. Uji normalitas data dengan uji lilliefors

\begin{tabular}{|c|c|c|c|c|}
\hline No & Latihan & Lo & Lt & Keterangan \\
\hline 1 & Pree Test & 0.1159 & 0.2200 & Normal \\
\hline 2 & Pos Test & 0.1331 & 0.2200 & Normal \\
\hline
\end{tabular}

Pada tabel di atas dapat dilihat bahwa hasil Lo variabel hasil daya ledak otot lengan atlet lebih kecil dari Lt, maka dapat disimpulkan bahwa data berdistribusi normal.

\section{d. Pengujian Hipotesis}

Untuk menguji apakah hipotesis yang diajukan dalam penelitian ini diterima keberadaannya atau tidak maka dilakukan pengujian data yang memakai uji-t pengujian hipotesis ini dapat dikemukakan sebagai berikut:

Dari analisis yang dilakukan, nilai $t_{\text {hitung }}$ antara tes awal dan tes akhir latihan beban menggunakan bench press terhadap daya ledak otot lengan atlet menunjukkan angka sebesar 6.42 selanjutnya nilai yang diperoleh dibandingkan dengan $t_{\text {tabel }}$ pada taraf signifikan 0.05 dengan derajat kebebasan $\mathrm{N}-1$ (14) ternyata nilai yang diperoleh adalah 2.15 hal ini menunjukkan bahwa nilai $t_{\text {hitung }}(6.42)>\mathrm{t}_{\text {tabel }}(2.15)$ dengan demikian dapat disimpulkan bahwa hipotesis yang menyatakan terdapat pengaruh latihan beban menggunakan bench press terhadap daya ledak otot lengan atlet UK karate UNP dapat diterima keberadaannya.

\section{PEMBAHASAN}

Daya ledak otot lengan dipengaruhi oleh kekuatan dan kecepatan kontraksi (Nossek dalam Arsil, 2008:74). Kekuatan merupakan salah satu komponen yang sangat penting untuk menunjang aktivitas fisik, khususnya dalam berolahraga. Komponen ini mutlak diperlukan untuk meraih prestasi puncak. Hal ini Syafruddin dalam Fachreza, (2010:20) bahwa, "Setiap penampilan dalam olahraga memerlukan kekuatan otot disamping unsur-unsur lainnya yang diperlukan". Kecepatan kontraksi otot yang terkait (serabut otot lambat dan serabut otot cepat), besarnya beban yang digerakkan, kontraksi otot intra dan otot ekstra, panjang otot pada waktu kontraksi dan sudut sendi.

Daya ledak otot lengan adalah kemampuan seseorang mengarahkan kekuatan dengan cepat dalam waktu yang sangat singkat, serta untuk memberikan momentum yang paling baik pada otot lengan dalam suatu gerakan yang cepat dalam melakukan aktivitas olahraga. Untuk menentukan hasil pengaruh daya ledak otot lengan ditentukan dengan menggunakan uji-t, di mana hasil yang ditemukan terdapat pengaruh yang signifikan latihan beban menggunakan bench press terhadap peningkatan daya ledak otot lengan putera, bahwa terdapat pengaruh yang signifikan latihan beban menggunakan bench press terhadap peningkatan daya ledak otot lengan.

Hasil daya ledak otot lengan atlet sebelum dilakukan latihan beban menggunakan bench press, jika dibandingkan dengan norma Two Hand Medicine Ball Putt Test maka dapat ditentukan bahwa dari 15 orang atlet, sebanyak 10 orang atlet memiliki hasil daya ledak otot lengan pada klasifikasi kurang dan 5 orang atlet memiliki hasil daya ledak otot lengan pada klasifikasi kurang sekali. Sedangkan untuk kategori sempurna, baik sekali, baik dan cukup tidak ada. Hasil tes atlet yang paling rendah adalah 2.34 dan hasil tes atlet yang paling tinggi adalah 3.40. 


\section{MAJALAH ILMIAH}

http : //1ppm.upiyptk.ac . id/ojs 3/index.php/MAJALAHILMIAH/index

Kemudian hasil daya ledak otot lengan atlet sesudah dilakukan latihan beban menggunakan bench press, jika dibandingkan dengan norma Two Hand Medicine Ball Putt Test maka dapat ditentukan bahwa dari 15 orang atlet, sebanyak 11 orang atlet memiliki hasil daya ledak otot lengan pada klasifikasi kurang dan 4 orang atlet memiliki hasil daya ledak otot lengan pada klasifikasi kurang sekali. Sedangkan untuk kategori sempurna, baik sekali, baik dan cukup tidak ada. Hasil tes atlet yang paling rendah adalah 2.47 dan hasil tes atlet yang paling tinggi adalah 3.47.

Dari hasil di atas jelas bahwa perbedaaan kedua daya ledak otot lengan sebelum dan sesudah melakukan latihan beban menggunakan bench press. Daya ledak otot lengan sesudah diberikan perlakuan dengan latihan beban menggunakan bench press nampak jelas peningkatan, walau peningkatannya sedikit. Ini dapat dilihat dari selisih antara rata - rata setelah dilakukan latihan beban menggunakan bench press dengan rata-rata sebelum dilakukan latihan beban menggunakan bench press adalah 0.17.

Di mana sebelum diberikan perlakuan dengan latihan beban menggunakan bench press, 10 orang atlet daya ledak otot lengannya pada klasifikasi yang kurang dan 5 orang atlet daya ledak otot lengannya pada klasifikasi yang kurang sekali. Sedangkan setelah dilakukan latihan beban menggunakan bench press, atlet sudah ada peningkatan dari hasil tesnya yang meningkat sedikit, menjadi 11 orang atlet daya ledak otot lengannya pada klasifikasi yang kurang dan 4 orang atlet daya ledak otot lengannya pada klasifikasi yang kurang sekali.

Hasil daya ledak otot lengan dipengaruhi oleh faktor internal dan faktor eksternal. Menurut Syafruddin (2011:57)," Faktor internal adalah faktor yang berasal dalam, yaitu dari diri atlet itu sendiri dengan segala potensi yang dimilikinya, seperti kemampuan fisik, teknik, taktik, kemampuan mental. Sedangkan faktor eksternal adalah faktor yang berasal dari luar diri atlet, seperti faktor pelatih, pembina, iklim dan cuaca, gizi, sarana dan prasarana, organisasi, keluarga."

Bompa dalam Syafruddin (2011 : 72-73) mendefinisikan, "Daya ledak sebagai produk dari dua kemampuan yaitu kekuatan (Strength) dan kecepatan (Speed) untuk melakukan force maksimum dalam waktu yang cepat". Sedangkan pendapat Jonath dan Krempel dalam Syafruddin (2011:73) yang menjelaskan bahwa, "Daya ledak sebagai kemampuan kombinasi kekuatan dan kecepatan yang terealisasi dalam bentuk kemampuan otot untuk mengatasi beban dengan kecepatan kontraksi yang tinggi”.

Berdasarkan pendapat diatas dapat didefenisikan bahwa daya ledak otot lengan adalah kemampuan mengarahkan kekuatan otot lengan dengan cepat dalam waktu yang sangat singkat untuk memberikan momentum yang paling baik pada tubuh dalam suatu gerakan yang cepat untuk mencapai tujuan yang dikehendaki. Untuk meningkatkan daya ledak otot lengan banyak cara atau latihan yang dapat dilakukan, diantaranya latihan push up, gerobak dorong dan latihan beban. Kenyataannya bahwa latihan beban merupakan bentuk latihan yang paling efektif untuk meningkatkan daya ledak. Pemberian latihan beban menggunakan bench press akan menyebabkan daya ledak otot lengan meningkat, maka secara otomatis latihan beban menggunakan bench press akan berpengaruh terhadap daya ledak otot lengan.

\section{SIMPULAN DAN SARAN \\ Simpulan}

Dari hasil penelitian di atas maka dapat di ambil kesimpulan bahwa Terdapat pengaruh latihan beban menggunakan bench press terhadap daya ledak otot lengan atlet UK karate UNP terbukti dengan thitung $(6.42)>t_{\text {tabel }}(2.15)$ pada $\alpha=0.05$. 


\section{MAJALAH ILMIAH}

http://1ppm.upiyptk.ac.id/ojs3/index.php/MAJALAHILMIAH/index

\section{Saran}

Berdasarkan hasil penelitian yang telah diuraikan di atas, maka adapun saran yang dapat penulis berikan dalam penelitian ini adalah sebagai berikut:

1. Bagi atlet karate UK UNP agar dapat meningkatkan kemampuan daya ledak otot lengan karena untuk meraih prestasi dalam beladiri Karate dibutuhkan pukulan yang kuat.

2. Bagi pelatih agar menggunakan latihan beban brench press untuk meningkatkan daya ledak otot lengan atlet Karate UK UNP.

\section{DAFTAR PUSTAKA}

Aderai. 2006. Aderai Gaya Hidup Sehat Fitnes Dan Binaraga. Jakarta : Bola.

Arsil. 2008. Pembinaan Kondisi Fisik. Padang : FIK-UNP.

Fachreza, Willy. 2010. Kontribusi Daya Ledak Otot Lengan Dengan Kelentukan Terhadap Kemampuan Hit Dalam Permainan Hoki Atlet Hoki Fakultas Ilmu Keolahragaan Universitas Negeri Padang (Skripsi). Padang : FIK UNP.

Febrina, Cory. 2009. Pengaruh Metode Latihan Sistem Set Dan Sirkuit Terhadap Peningkatan Kemampuan Daya Ledak Otot Lengan Pada Atlet Bolabasket FIK UNP (Skripsi). Padang : FIK UNP.

Hamid, Apris. 2007. Teknik Dasar Karate. Padang : Pramuda Design.

Hardiansyah Sefri. 2017. The Influence of Circuit Training Method on The Enhancement of Physical Fitness of Sports Education Department Students. Proceedings The $1^{\text {st }}$ Yogyakarta International Seminar on Health, Physical Education, and Sports Science: Yogyakarta. URL: http://yishpess.uny.ac.id/content/proceeding/541__Sefri_Hardiansyah.pdf

http://www.shocktreatment.com.au/arm\%20muscle.gif \{Access Minggu, 16 September 2018: 08.50\}.

Martinel. 2008. Kontribusi Daya Tahan Kekuatan Otot Lengan Terhadap Kemampuan Pukulan Chudan Tsuki Atlet Pra-Pon Forki Sumatera Barat (Skripsi). Padang : FIK UNP.

Syafruddin. 2011. Ilmu Kepelatihan Olahraga. Padang : UNP PRESS 